\title{
Direct and indirect shoot organogenesis strategies for propagation and conservation of Abutilon ranadei Wooder \& Stapf - A critically endangered plant.
}

\author{
Snehal S. Patil ${ }^{1}$, Jyoti J. Mane1, Suraj D. Umdale', Jaykumar J. Chavan ${ }^{1,2, *}$ \\ ${ }^{1}$ Department of Botany, Yashavantrao Chavan Institute of Science, Satara, India \\ ${ }^{2}$ Department of Biotechnology, Yashavantrao Chavan Institute of Science, Satara, India
}

\begin{abstract}
The study aimed to evaluate the efficiency of direct and indirect organogenesis for large-scale multiplication, propagation and conservation of Abutilon ranadei, an endemic and critically endangered plant. Nodes and leaves from in vitro germinated seedlings were used as source of explants for direct and indirect shoot organogenesis respectively. High frequency shoot organogenesis $\mathbf{( 7 7 . 5 \% )}$ with $7.1 \pm 0.2$ shoots were achieved when nodes were cultured on MS medium with BAP (3.0 $\mathrm{mg} / \mathrm{l})$ and GA $(0.5 \mathrm{mg} / \mathrm{l})$. The best callus induction and proliferation response was achieved with 2,4-D $(2.0 \mathrm{mg} / \mathrm{l})$ and BAP $(1.5 \mathrm{mg} / \mathrm{l})$. Maximum response $(92.5 \%)$ for shoot regeneration from callus with $13 \pm 0.8$ number of shoots were obtained in MS medium fortified with KN $(1.5 \mathrm{mg} / \mathrm{l})$ and NAA $(0.4 \mathrm{mg} / \mathrm{l})$. Microshoots regenerated via direct as well as indirect organogenesis were rooted best in $1 / 2 \mathrm{MS}$ containing $1.5 \mathrm{mg} / \mathrm{l} \mathrm{IBA}$ and $1.0 \mathrm{mg} / \mathrm{l}$ BAP. The well rooted plantlets were successfully established in the soil.
\end{abstract}

Keywords: Abutilon ranadei, Callus, Critically endangered, Organogenesis, Propagation.

Accepted on May 30, 2017

\section{Introduction}

The genus Abutilon (family - Malvaceae) is one of the pharmaceutically important groups of the flowering plants. These plants are used for making ropes cordages, jute dyes, drugs, gum, wrapping cloths, tissue paper for making coarse cloth etc. $[1,2]$. Abutilon ranadei is endemic and critically endangered shrub known from few localities in the Northern Western Ghats of India [3]. It is the wild relative of the plants of the agricultural importance e.g. Abelmoschus, Gossipium etc. The key feature of this species is bell shaped corolla with pale purple petals and orange yellow tips which has ornamental value. Poor seed setting, seed germination and seed viability are the certain constrains in its survival in nature [3]. Therefore there is an urgent need for large-scale multiplication and restoration of natural populations of these species using biotechnological tools. In the present investigation, efficient protocols were developed for direct and indirect shoot organogenesis, large-scale multiplication, and subsequent plantlet regeneration for conservation of Abutilon ranadei.

\section{Experimental Details}

\section{Plant material, explant preparation and culture conditions}

Seeds of Abutilon ranadei were collected from Amba Ghat locality from the Northern Western Ghats. Healthy and dry seeds were washed in running tap water for 5 minutes and were rinsed with Tween-20 $(0.5 \% \mathrm{v} / \mathrm{v})$ for $10 \mathrm{~min}$ followed by washing with sterile distilled water. Surface sterilization of the seeds were done using freshly prepared $0.1 \% \mathrm{HgCl}_{2}$ solution for $4 \mathrm{~min}$ followed by three time washing with sterilized distilled water. The seeds were blotted on sterile filter paper and were transferred to Murashige and Skoog's Medium [4]. All the cultures were maintained at $25 \pm 2{ }^{\circ} \mathrm{C}$ with continuous illumination of 2000 Lux light by white cool fluorescence light. (Philips, India).

\section{Seed germination and establishment of cultures}

Sterilized seed were transferred to half and full strength MS basal medium for germination. Nodes from in vitro germinated plants were transferred to $1.0 \mathrm{mg} / \mathrm{l}$ (BAP) for shoot induction.

\section{Callus induction and proliferation}

Leaves of in vitro grown seedlings were transferred on MS medium supplemented with 2, 4-D $(0.5 \mathrm{mg} / \mathrm{l})$ for induction of callus. For proliferation, callus were transferred to the same media composition or medium supplemented with different concentrations and combination of 2, 4-D, and BAP.

\section{Shoot regeneration, in vitro rooting and acclimatization}

The nodes were inoculated in MS media with different concentrations and combinations of plant growth regulators (BAP, TDZ and GA) for direct shoot regeneration. However, leaf derived calli were transferred on MS medium supplemented with BAP, KN and NAA. Shoots derived via direct and indirect organogenesis were transferred to halfstrength MS medium containing different concentrations and combinations of IBA and BAP. Well rooted plantlets were 
Citation: Patil SS, Mane JJ, Umdale SD, Chavan JJ. Direct and indirect shoot organogenesis strategies for propagation and conservation of Abutilon ranadei Wooder \& Stapf - A critically endangered plant. Adv Cell Sci Tissue Cul 2017;1(1):5-8.

transferred in the plastic pots containing the coco peat, soil and sand $(1: 1: 1)$ for their ex vitro establishment. The roots were treated with Fungicide (Bavistin, 05\%, w/v) before transfer to the pots.

\section{Statistical analysis}

All the experiments were conducted in completely randomized design and were repeated twice with 30 replicates per treatment. Analyses of comparisons of means were performed using the Dunnett multiple comparison test.

\section{Result and Discussion}

Seeds were forming roots within a week after inoculation on half as well as full strength MS medium. However, the development of seedlings to complete plantlets was recorded highest in half strength MS medium Figure 1A.
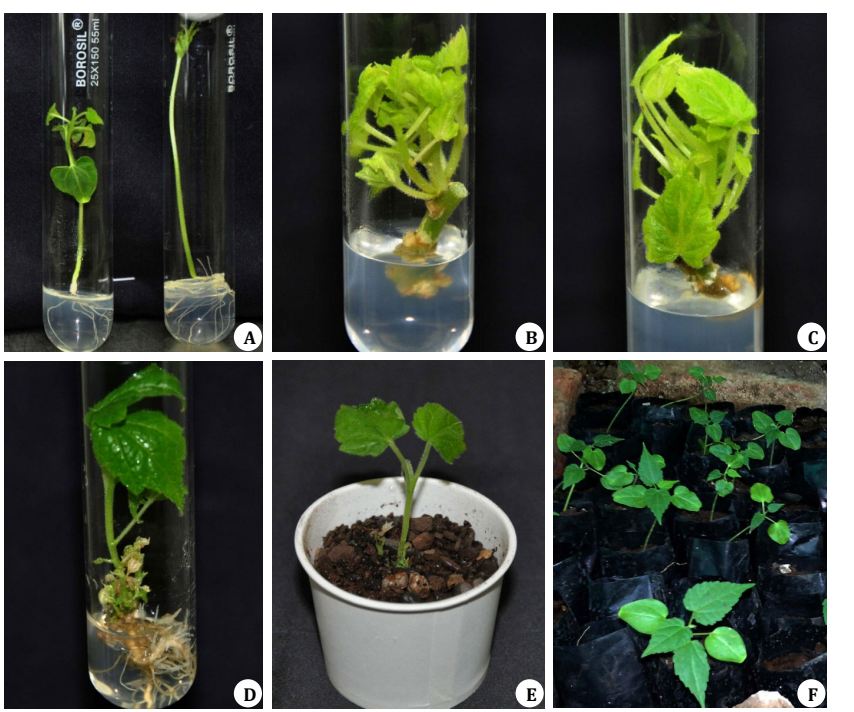

Figure 1. Direct shoot organogenesis of Abutilon ranadei; A: In vitro seed germination ( $1 / 2 M S$ basal), $B-C$ : Shoot multiplication (MS $+B A P$ $3.0 \mathrm{mg} / \mathrm{l}+\mathrm{GA} 0.5 \mathrm{mg} / \mathrm{l}) ; \mathrm{D}$ : In vitro rooting $(1 / 2 \mathrm{MS}+I B A 1.5 \mathrm{mg} / \mathrm{l}+$ BAP $1.0 \mathrm{mg} / \mathrm{l}) ; \mathrm{E}$ : Hardened plant and $\mathrm{F}$ : Well established plantlets into the soil.

Nodes and leaves from the in vitro germinated seedlings were used for the shoot multiplication and callus induction experiments respectively. The high multiplication rate $(77.5 \%)$ and shoot number $(7.1 \pm 0.2)$ were recorded in MS medium supplemented with BAP (3.0 mg/l) and GA $(0.5 \mathrm{mg} / \mathrm{l})$ (Figure 1B-1C).

The morphogenic response of nodal explants cultured on MS medium with different plant growth regulators are presented in Table 1 .

Table 1. Direct shoot organogenesis from nodal explants of Abutilon ranadei.

\begin{tabular}{|c|c|c|c|c|c|}
\hline Sr. No. & PGRs & $\begin{array}{l}\text { Conc. } \\
\text { (mg/l) }\end{array}$ & $\begin{array}{l}\text { Response } \\
(\%)\end{array}$ & $\begin{array}{l}\text { No. of shoots } \\
\text { (mean } \pm S E)\end{array}$ & $\begin{array}{l}\text { Shoot length } \\
\text { (mean } \pm S E)\end{array}$ \\
\hline 1 & MS basal & & 0 & 0 & 0 \\
\hline 2 & & 1 & 37.5 & $1.3 \pm 0.3$ & $4.0 \pm 0.2$ \\
\hline
\end{tabular}

\begin{tabular}{|c|c|c|c|c|c|}
\hline 3 & & 2 & 25 & $2.0 \pm 1.0$ & $4.2 \pm 1.5$ \\
\hline 4 & BAP & 3 & 65 & $5.3 \pm 0.6$ & $4.0 \pm 0.4$ \\
\hline 5 & & 4 & 57 & $3.0 \pm 0.9$ & $4.7 \pm 0.5$ \\
\hline 6 & & 5 & 62.5 & $3.0 \pm 0.2$ & $3.5 \pm 0.8$ \\
\hline 7 & & 1 & 25 & $1.1 \pm 0.2$ & $2.2 \pm 1.2$ \\
\hline 8 & & 2 & 37.5 & $2.3 \pm 0.6$ & $1.4 \pm 0.9$ \\
\hline 9 & TDZ & 3 & 25 & $1.2 \pm 0.4$ & $1.3 \pm 0.3$ \\
\hline 10 & & 4 & 45 & $2.1 \pm 0.3$ & $1.4 \pm 0.4$ \\
\hline 11 & & 5 & 35 & $1.6 \pm 0.2$ & $0.8 \pm 0.1$ \\
\hline 12 & $\mathrm{BAP}+\mathrm{GA}$ & $\begin{array}{l}3.0+0 \\
5\end{array}$ & 77.5 & $7.1 \pm 0.2$ & $5.4 \pm 0.2$ \\
\hline 13 & & $\begin{array}{l}3.0+1 \\
0\end{array}$ & 65 & $6.3 \pm 0.1$ & $3.2 \pm 0.3$ \\
\hline 14 & & $\begin{array}{l}3.0+1 \\
5\end{array}$ & 65 & $5.5 \pm 1.0$ & $4.3 \pm 0.1$ \\
\hline 15 & & $\begin{array}{l}3.0+2 \\
0\end{array}$ & 62.5 & $5.0 \pm 0.3$ & $3.6 \pm 0.3$ \\
\hline
\end{tabular}

In Abutilon ranadei, callus formation varied significantly depending on the type and concentration of the plant growth regulators (Table 2).

Table 2. Callus induction and proliferation from leaf explants of Abutilon ranadei.

\begin{tabular}{|c|c|c|c|c|}
\hline Sr. No. & PGR & $\begin{array}{l}\text { Conc. } \\
\text { (mg/l) }\end{array}$ & $\begin{array}{l}\text { Response } \\
(\%)\end{array}$ & Remark \\
\hline 1 & MS basal & - & - & - \\
\hline \multirow[t]{6}{*}{2} & $2,4-D$ & 0.5 & 45 & Only swelling \\
\hline & & 1 & 60 & Fluorescent green \\
\hline & & 1.5 & 55 & Embryogenic \\
\hline & & 2 & 75 & Soft, light green \\
\hline & & 2.5 & 60 & Brownish, friable \\
\hline & & 3 & 50 & Greenish, semi-hard \\
\hline \multirow[t]{5}{*}{3} & $2,4-\mathrm{D}+$ & $2.0+0.5$ & 70 & Green, compact \\
\hline & BAP & $2.0+1.0$ & 85 & pale yellow, Watery \\
\hline & & $2.0+1.5$ & 95 & Whitish, friable, watery \\
\hline & & $2.0+2.0$ & 80 & Whitish, friable, watery \\
\hline & & $2.0+2.5$ & 60 & Greenish, watery \\
\hline
\end{tabular}

The cut ends of the leaves showed the earliest sign of callus formation within 2 weeks of culture. The leaf discs cultured on PGR free MS medium failed to induce the callus. Callus induced on the 2, 4-D supplemented medium showed brownish appearance (Figure 2A). 


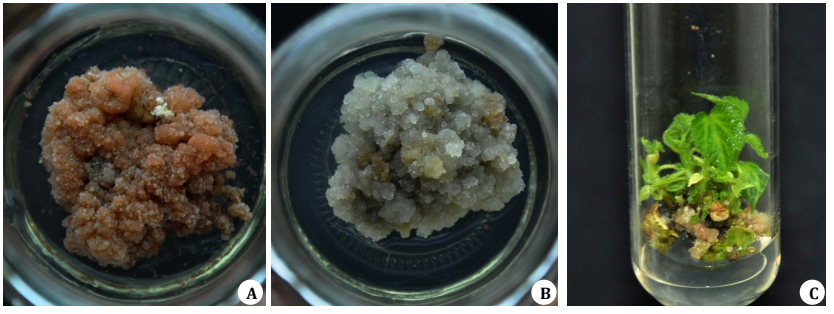

Figure 2. Indirect shoot organogenesis of A. ranadei; A: Callus induction and proliferation $(M S+2,4-D 2.0 \mathrm{mg} / \mathrm{l}) ; \quad B:$ Callus induction and proliferation $(M S+2,4-D 2.0 \mathrm{mg} / \mathrm{l}+B A P 1.5 \mathrm{mg} / \mathrm{l})$ and $C$ : Shoot organogenesis from callus $(M S+K N 1.5 \mathrm{mg} / \mathrm{l}+\mathrm{NAA} 0.4$ $m g / l)$.

Callus induction and proliferation was found optimal (95\%) on MS medium supplemented with 2, 4-D (2.0 mg/l) and BAP (BAP $1.5 \mathrm{mg} / \mathrm{l}$ ) (Table 2).
In this media composition, whitish, friable and watery appearance callus was observed (Figure 2B). For proliferation, the calli were transferred to the same medium for their proliferation. Similarly, the requirement of same media composition for induction and proliferation of calli were reported in Swertia lawii [5].

To induce shoot, fresh calli from optimal media concentration was transferred to MS media supplemented with various concentrations of BAP and $\mathrm{KN}$ with different concentrations of NAA. The shoot induction response was significantly affected by the type and concentration of plant growth regulators (Table $3)$.

Table 3. Indirect shoot organogenesis from leaf derived calli of Abutilon ranadei.

\begin{tabular}{|c|c|c|c|c|}
\hline PGRs & Conc. (mg/l) & Regeneration frequency (\%) & Number of shoots(mean \pm SE) & Length of shoot $(\mathrm{cm})$ (mean $\pm \mathrm{SE})$ \\
\hline Control & 0 & 0 & 0 & 0 \\
\hline \multirow[t]{4}{*}{ BAP } & 1 & 15 & $0.2 \pm 0.1 \mathrm{~ns}$ & $0.7 \pm 0.3$ \\
\hline & 2 & 22.5 & $0.7 \pm 0.3 \mathrm{~ns}$ & $1.1 \pm 0.2$ \\
\hline & 3.5 & 25 & $1.7 \pm 0.7$ & $1.3 \pm 1.1$ \\
\hline & 4 & 25 & $1.3 \pm 1.1$ & $1.4 \pm 0.4$ \\
\hline \multirow[t]{5}{*}{$\mathrm{KN}$} & 0.5 & 57.5 & $3.3 \pm 0.4$ & $2.3 \pm 0.3$ \\
\hline & 1 & 72.5 & $3.4 \pm 0.6$ & $2.1 \pm 0.2$ \\
\hline & 1.5 & 85 & $5.6 \pm 0.1$ & $3.0 \pm 0.4$ \\
\hline & 2 & 67.5 & $5.2 \pm 0.8$ & $2.1 \pm 0.6$ \\
\hline & 2.5 & 62.5 & $4.1 \pm 0.2$ & $2.5 \pm 1.2$ \\
\hline \multirow[t]{4}{*}{$\mathrm{KN}+\mathrm{NAA}$} & $1.5+0.2$ & 77.5 & $8.3 \pm 0.1$ & $4.2 \pm 0.4$ \\
\hline & $1.5+0.4$ & 92.5 & $13.1 \pm 0.8$ & $4.3 \pm 0.3$ \\
\hline & $1.5+0.6$ & 85 & $9.0 \pm 0.3$ & $3.5 \pm 1.0$ \\
\hline & $1.5+0.8$ & 75 & $6.1 \pm 0.7$ & $3.0 \pm 0.9$ \\
\hline
\end{tabular}

Optimum shoot formation (92.5\%) with $13.1 \pm 0.8$ number of shoots was achieved on MS medium supplemented with KN $(1.5 \mathrm{mg} / \mathrm{l})$ in combination with NAA $(0.4 \mathrm{mg} / \mathrm{l})$ (Figure $2 \mathrm{C})$. These findings are in accordance with the previous report on $A$. indicum where combination of KN and NAA proved superior for induction of shoots from leaf derived callus [6]. The in vitro rooting responses in microshoots of Abutilon ranadei are presented in Table 4 . The highest rooting frequency (85\%) was achieved when in vitro regenerated shoots were transferred to $1 / 2 \mathrm{MS}$ medium supplemented with IBA $(1.5 \mathrm{mg} / \mathrm{l})$ with BAP (1.0 mg/l) (Table 4 and Figure 1D). However, singular supplementation of auxin was necessary for some the medicinal and horticultural plants [7]. The well rooted plantlets were successfully transferred to the soil with $82 \%$ of survival rate and with no sign of morphological differences (Figure 1EF).

Table 4: In vitro rooting in microshoots of Abutilon ranadei.

\begin{tabular}{llll}
\hline Growth regulators $(\mathrm{mg} / \mathrm{l})$ & $\%$ response & $\begin{array}{l}\text { Roots } / \text { shoot } \\
\text { (mean } \pm \text { SE) }\end{array}$ & $\begin{array}{l}\text { Root length } \\
\text { (cm) (mean } \pm \text { SE) }\end{array}$ \\
\hline IBA & BAP & 00 & 0.0 \\
\hline $1 / 2$ MS basal medium & & 0.0 \\
\hline
\end{tabular}


Citation: Patil SS, Mane JJ, Umdale SD, Chavan JJ. Direct and indirect shoot organogenesis strategies for propagation and conservation of Abutilon ranadei Wooder \& Stapf - A critically endangered plant. Adv Cell Sci Tissue Cul 2017;1(1):5-8.

\begin{tabular}{lllll}
\hline 0.5 & 45 & $1.6 \pm 0.4$ & $1.5 \pm 0.2$ \\
\hline 1.0 & 60 & $2.4 \pm 1.0$ & $2.1 \pm 0.7$ \\
\hline 1.5 & 65 & $3.7 \pm 0.2$ & $1.7 \pm 0.4$ \\
\hline 2.0 & 55 & $1.9 \pm 0.4$ & $1.9 \pm 0.4$ \\
\hline 1.5 & 65 & $4.4 \pm 0.2$ & $3.2 \pm 1.1$ \\
\hline 1.5 & 1.0 & 85 & $2.3 \pm 0.1$ & $2.1 \pm 0.3$ \\
\hline 1.5 & 1.5 & 50 & $2.9 \pm 0.4$ & $2.6 \pm 0.1$ \\
\hline
\end{tabular}

In conclusion, an efficient direct and indirect shoot organogenesis protocols were developed for large-scale multiplication, propagation and conservation of Abutilon ranadei. This is the first report on in vitro propagation of this critically endangered plant. This protocol will be helpful for conservation of other Abutilon spp. as well as medicinally important species.

\section{Acknowledgement}

Authors are grateful to Head, Department of Botany and Principal, Yashavantrao Chavan Institute of Science, Satara for providing necessary laboratory facilities and for encouragement. We also sincerely thank to Research Advisory Committee of the institute for financial assistance. We indebted to Dr. Sharad Kambale, Department of Botany, Shivaji University, Kolhapur for helping with the plant collection and its authentication.

\section{References}

1. Singh V, Mishra UC, Khare GC, et al. A neutral seed gum from Abutilon indicum. Carbohydrate Polymers 1997;33(2):203-5.

2. Matlawska I, Sikorska M. Flavonoid compounds in the flowers of Abutilon indicum (L.) Sweet (Malvaceae). Acta Poloniac Pharmaceutica 2002;59(3):227-9.

3. Survase SA, Pokle DS. Seed germination of Abutilon ranadei Woodr. \& Stapf. critically endangered species in
Western Ghats, Maharashtra. Indian Journal of Plant Sciences 2013;2(1):55-8.

4. Murashige T, Skoog F. A revised medium for rapid growth and bioassays with tobacco tissue cultures. Physiol Plant 1962;15(2):473-97.

5. Kshirsagar PR, Chavan JJ, Umdale SD, et al. Highly efficient in vitro regeneration, establishment of callus and cell suspension cultures and RAPD analysis of regenerants of Swertia lawii Burkill. Biotechnology Reports 2015;6(43):79-84.

6. Rout MM, Mishra M, Das R. In vitro micropropagation of Abutilon indicum L. through leaf explants. Plant Tissue Cult Biotechnol 2009;19:177-84.

7. Chavan JJ, Gaikwad NB, Yadav SR. High multiplication frequency and genetic stability analysis of Ceropegia panchganiensis, a threatened ornamental plant of Western Ghats: Conservation implications. Sci Horti 2013;161(1): 134-42.

\section{*Correspondence to:}

Dr. Jaykumar J Chavan

Department of Botany, Yashavantrao Chavan Institute of Science

India

Phone: +91-2162-234392

Email: jaychavansu@gmail.com 